This item was submitted to Loughborough's Research Repository by the author.

Items in Figshare are protected by copyright, with all rights reserved, unless otherwise indicated.

\title{
What kind of love came to Professor Guildea? Robert Hichens, Oscar Wilde, and the Queer Ghosts of Hyde Park
}

\section{PLEASE CITE THE PUBLISHED VERSION}

http://dx.doi.org/10.5699/modelangrevi.111.2.0333

\section{PUBLISHER}

(C) Modern Humanities Research Association (MHRA)

\section{VERSION}

AM (Accepted Manuscript)

\section{PUBLISHER STATEMENT}

This work is made available according to the conditions of the Creative Commons Attribution-NonCommercialNoDerivatives 4.0 International (CC BY-NC-ND 4.0) licence. Full details of this licence are available at: https://creativecommons.org/licenses/by-nc-nd/4.0/

\section{LICENCE}

CC BY-NC-ND 4.0

\section{REPOSITORY RECORD}

Freeman, Nick. 2016. "What Kind of Love Came to Professor Guildea? Robert Hichens, Oscar Wilde, and the Queer Ghosts of Hyde Park”. Loughborough University. https://hdl.handle.net/2134/19617. 
Abstract: This article examines the ways in which ghost stories by Robert Hichens (1864-1950) inhabit the repressive sexual climate that followed the imprisonment of Oscar Wilde in 1895. Through a close reading of Tongues of Conscience (1900) and particularly 'How Love Came to Professor Guildea', it argues that Hichens used the ghost story as a mask for more complex investigations of homoeroticism, desire, and denial, and that the 'morbidity' contemporary critics recognized but could not pin down is closely linked to the story's sexual ambivalence.

\section{What Kind of Love Came to Professor Guildea? Robert Hichens, Oscar Wilde, and the Queer Ghosts of Hyde Park}

\section{Situating Hichens}

Robert Hichens is today remembered largely for his satire of Oscar Wilde, The Green Carnation (1894). Nowadays he is overshadowed by his namesake, a crewman on the Titanic, but for the best part of fifty years he was a significant commercial presence in English fiction, producing best-sellers such as The Garden of Allah (1904) and Bella-Donna (1909), and enjoying a sizeable following in Britain and North America, his work frequently adapted for stage and screen.

Such success (and longevity) is, in some ways, surprizing for as Richard Bleiler says in an overview of his career, he was essentially a pessimist whose judgement of character was often 'cruel' and who tended to shun 'the traditional happy ending. ${ }^{1}$ These attitudes are unexpected in a romantic novelist but were seen to good effect in fiction with a melodramatic criminal element, such as The Paradine Case (1933, later filmed by Alfred Hitchcock), and still more so in his supernatural and Gothic tales of the fin de siècle.

From such an outline, Hichens appears as an adaptable and opportunistic author of commercial fiction, a 'skilled craftsman' rather than an important literary figure. ${ }^{2}$ The editors of Edwardian Fiction: An Oxford Companion (1997) argue that 'versatility, amounting to a failure to fulfil the potential his talents seemed to promise, was to be a permanent feature of Hichens's career', whilst even his autobiography is characterized as 'tired and unrevealing. ${ }^{3}$ Most of his work has long been out-of-print and has received little critical attention. Discussing The Garden of Allah in 1972, Claud Cockburn observed how it posed 'moral problems' of a romantic and sexual nature with 'the repetitive insistence of a tomtom'. A 'modern reader' was likely to find such writing 'heavy going', he added, consigning Hichens to an Edwardian era of 'steamy religiosity' susceptible to his 'particular kind of hocus-pocus'. ${ }^{4}$ The purpose of this essay is less to take issue with these characterizations - though they are not wholly fair - than to explore the ways in which a particular aspect of 'moral problems' is rooted in late-Victorian anxieties concerning male same-sex desire. A great deal of attention has been paid to the treatment of such issues in the work of canonical 'queer' writers such as Oscar Wilde, Henry James, and E. M. Forster, but

\footnotetext{
${ }^{1}$ Richard Bleiler, 'Robert S. Hichens (14 November 1864 - 20 July 1950)', Dictionary of Literary Biography Volume 153: Late-Victorian and Edwardian British Novelists, First Series, ed. by George M. Johnson (Detroit: Bruccoli Clark Laymon, 1995), p.109.

${ }^{2}$ Claud Cockburn, Bestseller: The Books that Everyone Read, 1900-1939 (1972; Harmondsworth: Penguin, 1975), p. 56.

${ }^{3}$ Edwardian Fiction: An Oxford Companion, ed. by Sandra Kemp, Charlotte Mitchell, and David Trotter (Oxford: Oxford University Press, 1997), p. 183.

${ }^{4}$ Cockburn, pp. 56, 52.
} 
more popular fiction of the 1900s has often evaded such detailed scrutiny, something which has produced a skewed picture of the period's sexual politics. Much can be learned from examining a writer who was commercially successful and widely discussed at the turn of the twentieth century, but whose wider contribution to our understanding of the fin de siècle has yet to be properly recognized. That Hichens was able to explore taboo topics in mainstream fiction only five years after Wilde's imprisonment for Gross Indecency says much about his subtlety, his understanding of his audiences, and the ways in which literary fantasy could be used as a smokescreen for more troubling speculation.

Hichens wrote a number of Gothic tales, moving beyond the ghost story to dramatize reincarnation in 'The Return of the Soul', combine it with modish anti-vivisection agitation in 'The Black Spaniel', and explore soul transference and the sort of psychic vampirism later found in the novels of Dion Fortune. ${ }^{5}$ Interested in occult matters throughout his life, Hichens interviewed psychics and spiritualists when training as a journalist in the late 1880s, featured them in his novels, and, like Wilde, consulted palmists before making important decisions. ${ }^{6}$ Some of these streams flowed into Tongues of Conscience (1900) and, in particular, into the only one of his short stories to have endured. The disquieting 'How Love Came to Professor Guildea' combines a highly original haunting with a debate between science and religion and a strikingly homoerotic undercurrent. It may be Hichens's masterpiece as well as the work in which, as Bleiler remarks, his 'unhappiness receives its clearest expression'.

Tongues of Conscience was a collection of five stories which appeared in the autumn of 1900, part of a strong Methuen six shilling list headed by Marie Corelli's The Master Christian and W. W. Jacobs's A Master of Craft. In the run-up to Christmas, readers who enjoyed ghost stories could choose between Hichens's quintet, the more sensational fare in Richard Marsh's The Seen and the Unseen, and the wryly amusing 'The Third Person' from Henry James's The Soft Side. The major literary event of the season was probably Joseph Conrad's Lord Jim, but the advertising columns indicated that literature was increasingly overshadowed by politics and conflict in promoting a number of Boer War books - Methuen's list included Filson Young's The Relief of Mafeking. Numerous titles clamoured for coverage in the newspapers' book pages, but Hichens was a rising star, even if the commercial breakthrough of The Garden of Allah was still four years away. Consequently, he was reviewed by prominent periodicals and the London dailies, as well as throughout the provinces. He later recalled that Tongues of Conscience brought him 'great praise', but this view, like many other claims in Hichens's memoirs, is not entirely accurate. ${ }^{8}$ In general, critics were impressed by his stories' stylistic elegance and the depth of their psychological insight, but there were some reservations where content was concerned. One writer remarked that they '[left] an unpleasant taste behind, despite their literary excellence'; another felt they 'add[ed] little to [their] author's reputation'. ' The Glasgow Herald detected 'a brooding, eerie feeling which clings to the reader long after he has laid aside this book', while the Leeds Mercury

\footnotetext{
${ }^{5}$ The Folly of Eustace and Other Stories (London: William Heinemann, 1896), The Black Spaniel and Other Stories (London: Methuen, 1905), Flames, A London Phantasy (London: William Heinemann, 1897), The Dweller on the Threshold (London: Methuen, 1911).

${ }^{6}$ See Yesterday: The Autobiography of Robert Hichens (London: Cassell, 1947), pp. 77-80, 151-53.

${ }^{7}$ Bleiler, p. 113.

${ }^{8}$ Hichens, Yesterday, p. 101.

${ }^{9}$ Lloyd's Weekly Newspaper, 7 October 1900, p. 11; The Speaker, 27 October 1900, p. 104.
} 
thought them 'gruesome' but 'fascinat[ing]'. The Pall Mall Gazette examined the collection in more detail, praising its 'daring invention', 'subtle psychological analysis', and 'the profound knowledge of the working of the human mind under abnormal conditions' to which its stories bore 'eloquent witness'. Punch also found the book 'fascinating', according it the honour of a parody, 'The Professor and the Autumn "Creeper", but judging that story's climax 'a little too emotionally contrived'. ${ }^{10}$ The concluding notion of love as a disease of the heart had, after all, appeared in very similar form in Arthur Conan Doyle's 'The Ring of Thoth' back in 1890.

These tentatively positive responses begin to indicate why Tongues of Conscience did not have lasting appeal. 'Gloom, Cimmerian gloom, envelops and depresses the reader as $\mathrm{Mr}$ Hichens guides him through the darkness of [these] five stories', announced the Pall Mall Gazette. The Saturday Review identified 'a faded aroma of sentimentality gone bad', ${ }^{11}$ a comment that sums up the collection's opening story, 'Sea Change'. ${ }^{12}$ This was the tale of a guilt-stricken painter, Sir Graham Hamilton, who is haunted by the ghost of Jack Pringle, a boy he had used as a model in a successful painting, 'Sea Urchin'. Hamilton had waxed lyrical about nautical adventure, and his stories encouraged Pringle to run away to sea, where he was drowned. In the course of an emotionally-complex story, Hichens seemed unsure as to whether he should dwell on Hamilton's self-corroding guilt, his attempts to explain himself to a sympathetic clergyman, or his model's vengeful return from the waves. What resulted was an unsatisfying amalgam of all three that the Saturday's reviewer, distinguishing between psychology and mere 'pathology', called 'hothouse studies of morbid emotions. ${ }^{13}$ The collection's third story, 'The Cry of the Child', deals with a young doctor who allows his unloved baby son to die from neglect while he is studying for his degree, and finds himself haunted by phantom sobbing remains a distressing concoction, the more so for the self-sacrifice of the doctor's wife, who brings him peace and some form of expiation at the cost of her own life. ${ }^{14}$

By the 1890s, the devices that had been such mainstays of the Christmas annuals' ghost stories were increasingly being burlesqued in works such as Wilde's 'The Canterville Ghost' (1887), Jerome K. Jerome's Told After Supper (1891), and H. G. Wells's 'The Red Room' (1896). Hichens, self-conscious of his artistic status, was forced to move into new territory, focusing more on the experience and consequences of haunting than on dramatic moments of materialization. In many respects, the ghost story's increasing concern with psychology suited him, since it allowed the eschewing of 'the conventional, white-robed, cloud-like figure' in order to dramatize the ways in which the supernatural, or a belief in it, acts upon the nerves and

\footnotetext{
${ }^{10}$ Glasgow Herald, 11 October 1900, p. 3; Leeds Mercury, 17 October 1900, p. 3; Pall Mall Gazette, 9 October 1900, p. 3; Punch; or, The London Charivari, 14 November 1900, p. 356.

${ }^{11}$ Saturday Review, 27 October 1900, p. 524.

${ }^{12}$ Hitchens, 'Sea Change', in Tongues of Conscience (London: Methuen, 1900), pp. 1-108.

${ }_{13}$ Saturday Review, 27 October 1900, p. 524.

${ }^{14}$ Hitchens, 'The Cry of the Child', in Tongues of Conscience, pp. 183-266. Hichens later claimed that he had been offered $£ 80$ for the story by the Pall Mall Magazine, which then rejected it as 'not "up to [the] mark"', leading him to publish it elsewhere for the extravagant sum of $f_{1} 100$. Yesterday, p. 56. Surprisingly in view of its subject matter, the story eventually appeared in Country Life, 59 (19 February 1898), pp. 225-38.
} 
character of those who encounter it. ${ }^{15}$ Hichens was also able to hide behind the arras of fantasy, a mode which allowed him to disguise his underlying preoccupations even as he indulged them, a duality much more difficult to manage in realist fiction. His ambiguous presentation of the supernatural was applauded by the Times, which placed 'Professor Guildea' on a par with Sheridan Le Fanu's 'The Watcher' (1847), admiring the way in which the protagonist's plight may be attributable to a ghost, 'the nerves, the brain, or the liver'. ${ }^{16}$ Other critics drew parallels with Poe and Guy de Maupassant's 'Le Horla' (1887), especially where 'Guildea' was concerned: the Speaker applauded it as 'a tale of pure horror'. However, as these reference points show, Hichens was poised between techniques associated with mid-century Gothic (Poe, Le Fanu) and the psychological realism of contemporary French fiction without yet being able to manage their seamless amalgamation.

During the 1890s, Vernon Lee's Hauntings (1890), and the ghostly tales of Henry James most famously, 'The Turn of the Screw' (The Two Magics, 1898) - had set new standards for both psychological sophistication and fundamentally ambiguous content, and over the next thirty years their suavely treacherous approach would attract such luminaries as Oliver Onions, Walter de la Mare, L. P. Hartley, and Elizabeth Bowen. In 1900 though, the ghost story was at an awkward moment in its evolution, with its increasing narrative and psychological sophistication making it ever more respectable as a literary form while at the same time risking the reduction of its commercial possibilities through over-refinement. Offered a text that advertised itself as a ghost story, many readers wanted it to be just that, rather than probing buried memories or dramatizing what the narrator of Heart of Darkness (1901) calls 'inconclusive experiences'. ${ }^{17}$ Hichens, too subtle for popular success on the scale of Corelli or Hall Caine, but not quite subtle enough to rival James, a writer to whom he paid the compliment of homage in several works, may have suffered as a consequence, though his ability to shift from melodrama to romance to mystery to comic satire prevented him from being pigeonholed as a writer of 'shockers'. ${ }^{18}$ 'How Love Came to Professor Guildea' would languish in obscurity until its rediscovery by Dorothy L. Sayers, who commented on its 'delicious nausea' in the first volume of her Great Stories of Detection (1928). ${ }^{19}$ It has since been reprinted in anthologies such as Alberto Manguel's Black. Water (1983) but has received little discussion beyond its acknowledgement in surveys of 'classic' ghost stories.

\footnotetext{
${ }^{15}$ Hichens, 'How Love Came to Professor Guildea', in Tongues of Conscience, pp. 267-340 (p. 305). Further references to the story are given parenthetically in the body of the article.

${ }^{16}$ Times (London), 27 December 1900, p. 10.

${ }^{17}$ Joseph Conrad, Heart of Darkness, ed. by Robert Hampson (London: Penguin, 1995), p. 18.

${ }^{18}$ Hichens knew James quite well during the late 1890s (Yesterday, p. 55). Adeline R. Tintner notes borrowings or tributes to James in The Londoners (1898) and Barbary Sheep (1907), and sees The Dweller on the Threshold (1911) as a reworking of 'The Jolly Corner' (1907). She does however point out that the influence may have been mutual, suggesting that the African scenes of The Golden Bowl (1904) may have been inspired by those in The Garden of Allah (1904). Henry James's Legacy: The Afterlife of His Figure and Fiction (Baton Rouge: Louisiana University Press, 1998), pp. $152-54$.

${ }^{19}$ Dorothy L. Sayers, 'Introduction' to Great Stories of Detection (London: Victor Gollancz, 1928), p. 46. Sayers and Hichens agreed a fee of $£ 20$ for a story the editor considered 'delightfully unpleasant' (Sayers refused to pay Algernon Blackwood $f^{21}$ for his story, 'Secret Worship').
} 
'Professor Guildea' is, on the surface, a simple account of a workaholic and misanthropic scientist who, despite the wise counsel of his solitary friend, Father Murchison, rejects love, only to find himself pursued by a blindly affectionate spirit which invades all aspects of his life. 'Learn to give it your love and it may go', Murchison advises (p. 336), but Guildea cannot do this. His outburst - 'Hatred! I can give it that, - always that, nothing but that - hatred, hatred' - at last drives the spirit from home, but hastens his death from 'failure of the heart' (p. 339). 'He should have lived very differently', says the doctor who ponders the 'shocking expression of terror on his convulsed face' (p. 339), a judgement with which the priest can only concur. The story is suggestive yet vague where the nature of the apparition is concerned, with the Morning Post observing that Hichens had followed Le Fanu's lead in emphasizing that 'the indefinite is the only treatment of the supernatural'. '[W] are never told exactly what it is that haunts Professor Guildea', the reviewer continues, 'but we learn quite enough to realize the full horror of inspiring an unrequited affection in a ghost'. ${ }^{20}$ Guildea and Murchison watch in mounting alarm as an unseen presence fondles a tame parrot (which the Professor is at pains to term an experimental subject rather than a pet), and the situation takes a turn for the worse when Guildea is molested on his way to bed, feeling a 'gentle, but determined, push against me, as if to coax me and attract my attention' (p. 327). He flees up the staircase, but is importuned again on the entrance to his bedroom where, he tells Murchison, 'I felt the thing entering with me' and 'squeezing, with loathsome, sickening tenderness against my side' (p. 327).

Not content with violating the intimate spaces of Guildea's home, the apparition follows the Professor across the Channel, where he is due to give a public lecture. 'It accompanied me to Paris', Guildea says, 'stayed with me there, pursued me to the lecture hall, pressed against me, caressed me while I was speaking' (p. 334). This elision of the academic and the erotic is overwhelming, and Guildea collapses in the lecture room, the Times reporting that he has obviously been exhausted by his work. Back in London before the final tragedy, Guildea resembles 'a man emaciated by a long and severe illness' whose 'wide open eyes' display 'an expression of fixed horror' (p. 333). It would seem that his resistance to the spirit's attentions have obviously driven him to bodily as well as psychological exhaustion. The scientific rationalist fights to the end, but against what, and why?

\section{A Morbid Tale}

The title of Hichens's collection implied the stirrings of guilt, the hidden internal promptings to redress the wrongs, or perceived wrongs, of the past. In 'Sea Change', Hamilton cannot rid himself of his sense of responsibility for his model's death, while Mrs Errington's dismissal of a mendicant in 'The Lady and the Beggar' leaves her preoccupied with his fate: 'Till I relieve that man's wants', she tells her son, 'I shall have no peace'. ${ }^{21}$ Maurice Dale, the doctor in 'The Cry of the Child' who allowed his illegitimate child to die of neglect, suffers too, driven almost mad by a combination of remorse and possible supernatural intervention. Even the non-ghostly 'William Foster' features a man caught between his 'real' life and the contrasting associations of his literary

Warwick University Library, Victor Gollancz Personal Papers, MSS.318/3/DLS 283 (Sayers to Hichens, 28 February 1928).

${ }^{20}$ Morning Post, 26 December 1900, p. 6.

${ }^{21}$ Hitchens, 'The Lady and the Beggar', in Tongues of Conscience, pp. 341-68 (p. 366). 
persona in a melodramatic reworking of James's 'The Author of Beltraffio' (1884). ${ }^{22}$ Compared with these characters, Guildea's conscience seems clear, but while he feels no guilt about his life of emotional self-sufficiency, much about him remains obscure. Reviewers of Tongues of Conscience repeatedly noted a 'morbid' element in Hichens's stories, their reiteration of the word perhaps one reason for the book's limited popularity. ${ }^{23}$ The pairing of what the Leeds Mercury termed 'a hyper-morbid tendency' and unwholesomeness is a significant one, and even Guildea worries that he has 'a sickly, morbid, rotten imagination' (p. 298). If his anguish is associated with such ideas, much hinges on the precise meaning of the term 'morbid', or rather, the connotations it had acquired in an era of artistic decadence and high-profile sexual transgressions.

'Professor Guildea' emerges from what George Gissing termed the 'sexual anarchy' of the fin de siècle, a time when, as Elaine Showalter writes, 'all the laws that governed sexual identity and behaviour seemed to be breaking down'. ${ }^{24}$ As a young journalist and would-be writer in 1890s London, Hichens saw this at first hand, particularly through his involvement with the circle of homosexual men surrounding Oscar Wilde. His own sexuality remains mysterious, though recent critics have suggested that he shared Wilde's 'homosexual proclivities'. ${ }^{25} \mathrm{He}$ never married, claiming somewhat unconvincingly that this was due to a heartbreaking entanglement with a young woman early in life, and his stories display 'a curious loathing of heterosexual physical relationships and a distrust of any erotic impulse, no matter how innocent or quietly suppressed'. ${ }^{26}$ In later life he was keen to distance himself from Wilde, admitting to only 'four or possibly five' meetings with him, but a visit to Egypt in the winter of 1893-94, ostensibly undertaken for health reasons (his memoirs assert that he went cruising down the Nile when convalescing from peritonitis, having at one point been so ill he could only subsist on 'sips of champagne'), brought him into contact with Lord Alfred 'Bosie' Douglas, the society novelist, E. F. Benson, and the wit and man-about-town, Reggie Turner, a familiar figure in London's

${ }^{22}$ Hitchens, 'William Foster', in Tongues of Conscience, pp. 109-83.

${ }^{23}$ The Pall Mall Gazette identified a 'merciless and persistent morbidity', the Morning Post felt '[t]he tongues of Mr Hichens' conscience discourse in a very morbid vein’ (26 December 1900, p. 6), while Lloyd's Weekly Newspaper acknowledged the 'power' of the stories but pronounced them 'very morbid' (7 October 1900, p. 11). The Saturday Review and the Speaker made similar observations, though other critics were inclined to place such attitudes in a more reassuring context, with the Leeds Mercury affirming that 'his morbidity has a safety valve in action' and is thus 'never unwholesome' (17 October 1900, p. 3), and the Times insisting that, though Hichens's 'talent has a morbid bent [...] his morals are all for the good' (27 December 1900, p. 10). The Athenaeum felt the 'rather morbid narratives' managed to translate 'morbidness of ideas' into 'action', instead of 'strain[ing] after a "realistic" description of repulsive thought and actions' (13 October 1900, p. 478).

${ }^{24}$ Elaine Showalter, Sexual Anarchy: Gender and Culture at the Fin de Siècle (London: Bloomsbury, 1991), p. 3.

${ }^{25}$ Angela Kingston, Oscar Wilde as a Character in Victorian Fiction (Basingstoke: Palgrave Macmillan, 2007), p. 145. Dennis Denisoff's Aestheticism and Sexual Parody, 1840-1940 (Cambridge:

Cambridge University Press, 2001) maintains that 'Hichens was sexually attracted to men' (p. 115), while Neil McKenna's The Secret Life of Oscar Wilde(London: Century, 2003), comments on his 'sexual equivocations and self-loathing' (p. 410).

${ }^{26}$ Bleiler, p. 109. 
homosexual subculture whom Wilde dubbed 'the boy-snatcher of Clement's Inn'. ${ }^{27}$ All three were homosexual, and Benson's biographer remarks that while 'we do not know that they discussed anything more than the Pyramids, [i]t is impossible to believe that Wilde and his habits did not come into the conversation'. ${ }^{28}$ The friendships formed in Egypt endured in London, and on one notable occasion, Hichens's rooms in Buckingham Palace Road were the venue for 'a most hilarious and delightful evening' attended by Wilde, Douglas, Beerbohm, Turner, and several other young men. Perhaps the most significant encounter between Hichens and Wilde saw the playwright turn up 'one night with a comparatively youthful companion' and enjoy a whisky and soda and a cigarette before heading off towards his house in Tite Street. ${ }^{29}$

Hichens might therefore be seen as implicated in Wilde's world, but he was uncomfortable there and rather ungenerously parodied Wilde and Douglas in The Green Carnation, published anonymously in September 1894. The book captured the subject matter and style of their conversation with uncanny accuracy. Wilde dismissed it as 'middle-class and mediocre' in a letter to the Pall Mall Gazette, but confided to Ada Leverson that Hichens had 'talent' if not 'physical beauty' and was 'very clever' despite being a journalist. He was, Wilde said a 'doubting disciple', a man seemingly drawn to and yet sceptical of the Wildean gospel. ${ }^{30}$ The novel revelled in its ambivalence; that it was regarded by conservatives as being as subversive (but ridiculous) as Wilde himself can be seen from Punch's parody of it, 'The Decadent Guys', which ran shortly after Bonfire Night in November 1894. ${ }^{31}$

The Green Carnation went quickly through four impressions before Hichens and his publisher, William Heinemann, removed it from circulation in the spring of 1895. 'It seemed to us both in very doubtful taste to continue selling such a skit on a famous man who had got into trouble', Hichens recalled in 1948, shortly after the death of the obsessively litigious Bosie made a republication possible. ${ }^{32}$ Such comments suggest a straightforward satire, but as Richard Ellmann points out, the book was 'more like a documentary'. ${ }^{33}$ The result 'shimmered between

${ }^{27}$ Hichens, Yesterday, p. 66; Neil McKenna, The Secret Life of Oscar Wilde, p. 373. Hichens saw Wilde lecture at Bristol's Victoria Rooms while he was a schoolboy at nearby Clifton College in October 1884, and later witnessed his arrival at a London theatre accompanied 'five ultra-smart youths, all decorated with similar green carnations' in their button-holes (Yesterday, p. 69). This was alluded to in The Green Carnation, where the men 'all had the same walk, or rather waggle'. The Green Carnation (1894; London: Martin Secker, 1948), p. 15. As McKenna says, drawing on the not always reliable recollections of Frank Harris, Hichens saw Douglas fairly frequently in the spring and summer of 1894.

${ }^{28}$ Brian Masters, The Life of E. F. Benson (London: Chatto and Windus, 1991), pp. 108-09.

McKenna claims that Bosie, 'incapable of reticence or discretion [...] talked at length and with passion of his love for Oscar, of their sexual explorations and adventures together', though he gives no source for such claims (The Secret Life of Oscar Wilde p. 373). See too Stanley Weintraub, Reggie: A Portrait of Reginald Tumer (New York: George Braziller, 1965), pp. 50-55.

${ }^{29}$ Hichens, 'Introduction' to The Green Carnation, p. xi.

${ }^{30}$ Oscar Wilde, Complete Letters, ed. by Merlin Holland and Rupert Hart-Davis (London: Fourth Estate, 2000), pp. 617, 615.

${ }^{31}$ Punch, 10 November 1894, p. 225.

${ }^{32}$ Hichens, 'Introduction' to The Green Carnation, p. xvi.

${ }^{33}$ Richard Ellmann, Oscar Wilde (London: Hamish Hamilton, 1987), p. 400. 
ridicule and homage', celebrating the wit of its subjects even as it professed to deplore their behaviour and making Hichens's own position difficult to gauge. ${ }^{34}$

After the furore surrounding The Green Carnation, Hichens was always careful to cover his tracks, and the extent to which he explored the city's sexual underworld in the mid-1890s is now impossible to discover. Perhaps the Nile trip was motivated less by his poor health than a need to leave London - in the wake of the 1885 Criminal Law Amendment Act, men who met with other men in private, regardless of what took place between them, ran the risk of blackmail and damaging sexual insinuation. Wilde and Douglas had both suffered the noxious attentions of 'renters' who stole incriminating letters and extorted money for their return. 'Hichens' work is haunted by a horror of exposure', says John Clute, and it may be that this, and a concomitant fear of emotional self-revelation outside the sanctified confines of the Confessional, have their origins in the climate that grew up around the so-called 'Blackmailer's Charter'. ${ }^{35}$ Whether his satire of Wilde arose from commercial opportunism - he admitted that he was following in the footsteps of E. F. Benson's Dodo (1893) - from self-loathing, or from a more high-minded sense that Wilde's behaviour brought same-sex desire into disrepute, Hichens's detailed knowledge of aspects of the Wilde milieu suggests he was not an altogether innocent bystander. ${ }^{36} \mathrm{He}$ may not have been one of those who fled England in the wake of the events of May 1895, but he did not remain in London for much longer. 1898 had seen Lord Salisbury's government pass an amendment to the 1824 Vagrancy Act which stated that 'every male person who in any public place persistently solicits or importunes for immoral purposes shall be deemed a rogue and a vagabond and may be dealt with accordingly. ${ }^{37}$ The following year, Hichens was afflicted by a 'troublesome' nervous illness, and 'finding the endless noise and hurry and excitement of the town unendurable, he went abroad to look for the seclusion and quiet that were necessary for him' ${ }^{38}$ If Hichens was homosexual, the new legislation may have been further encouragement to leave the capital - as Kerry Powell points out, prosecutions (and convictions) for Gross Indecency were on the rise throughout the decade, not least because the 'evidentiary standard' for the offence and its vaguer variant, indecent assault, 'was much less stringent than for sodomy'. ${ }^{39}$ It is certainly suggestive that once out of England, Hichens spent much of his time in hotels in Sicily and North Africa, eventually purchasing property in Taormina in eastern Sicily:

\footnotetext{
${ }^{34}$ Nicholas Freeman, 1895: Drama, Disaster and Disgrace in Late Victorian Britain (Edinburgh: Edinburgh University Press, 2011), p. 14.

${ }^{35}$ John Clute, 'Hichens, Robert (Smythe) (1864-1950)', in The Encyclopedia of Fantasy, ed. by John Clute and John Grant (London: Orbit, 1997), p. 466.

${ }^{36}$ By this I mean that unlike many late-Victorians, Hichens may not have seen homosexuality as 'wrong' in itself. Rather, he deplored Wilde's public image and the effect this had upon perceptions of same-sex relationships.

${ }^{37}$ Antony Clayton, Decadent London (London: Historical Publications, 2005), p. 182.

38 'Robert Hichens', in St John Adcock, The Glory that was Grub Street (London: Sampson Low, Marston, 1928), p. 112.

${ }^{39}$ Kerry Powell, Acting Wilde: Victorian Sexuality, Theatre, and Oscar Wilde (Cambridge: Cambridge University Press, 2009), p. 141.
} 
Graham Robb notes the popularity of the town alongside Palermo, Syracuse, Tunis, and Algiers for late-nineteenth century 'Uranian' visitors. ${ }^{40}$

In such contexts, 'morbid' associations spread outwards from the OED's primary definitions of 'indicative of disease', 'unhealthy', and 'addicted to gloom' to those 'mental ideas which are "sickly" and "unwholesome". While one might expect a ghost story to be concerned with disease and impending death, 'morbid' was widely applied to decadent literature and art throughout the 1890s; Vincent O'Sullivan contributed a richly ironic essay, 'On the Kind of Fiction Called Morbid' to The Savoy in April 1896. ${ }^{41}$ Even before the condemnatory impetus was invigorated by Max Nordau's Entartung (1892, translated as Degeneration, 1895), the press regularly stuck the labels of 'morbid', 'unwholesome', and indeed 'unmanly' on such productions as Degas's L'Absinthe (first exhibited in England in 1893), Wilde's Salomé (1893) and the drawings by Aubrey Beardsley that accompanied it (1894), contributions to John Lane's 'Keynotes' series (1893 onwards), and, in the preface to one of them (Grant Allen's The British Barbarians (1895)), London itself, which entices 'the men of the villages' with '[s]trange decadent sins and morbid pleasures' ${ }^{42}$ These immoral practices might be summarized as prostitution, alcoholism, chainsmoking, drug use, and homosexuality; 'morbid' was much used in newspaper coverage of Wilde's trials and other sexual offences, and although Wilde himself had claimed 'No artist is ever morbid. The artist can express everything', the more reactionary elements of parliament, the press, the public, and the legal profession were quite prepared to disagree. ${ }^{43}$ The term was, for many journalists, useful code for sexual deviancy, an imprecise yet evocative cue that prompted all manner of sordid imaginings. Five years after Wilde's sentence, the dust was still settling on British literary culture. Tongues of Conscience, published only a month before Wilde's death, was, it seemed, 'legitimately' morbid because of its gloomy supernatural content, but at the same time it flirted with a less acceptable morbidity, particularly where 'Professor Guildea' was concerned.

\section{Queer Ghosts and Dangerous Places}

The location of Guildea's house, 100 Hyde Park Place, is crucial to any contextual reading of the story. This road, now the busy A402, runs between Victoria Gate and Marble Arch, connoting the wealth and status academics enjoyed in those balmy days, but also offering an implicit subversion of the Professor's determinedly celibate outlook, for 'there is a gate just opposite' that offers perpetual temptation (p. 272). One 'cold' and 'misty' night around eleven o'clock, when there are few people about, Guildea, his mind 'still full of work', is 'staring at the Park' when he spots a 'person - if it was a person - through the railings' (p. 285). Drawn to the figure on the park bench, Guildea puts on his hat and heads out to investigate, only to find that the bench is vacant. This leaves him with 'a most absurd sensation of disappointment, almost of anger' ( $p$.

\footnotetext{
${ }^{40}$ Graham Robb, 'Map of Uranian Europe' in his Strangers: Homosexual Love in the Nineteenth Century (London: Picador, 2003), pp. 278-79. Hichens subsequently insisted that he 'really loved London and London life. Most of my friends were there. [...] I liked better being in London than in almost any other place in the world I knew' (Yesterday, pp. 105, 122), a remark at odds with his comments to St John Adcock (above).

${ }^{41}$ Vincent O'Sullivan, 'On the Kind of Fiction Called Morbid', The Savoy No.2 (April, 1896), pp. $167-72$.

${ }^{42}$ Grant Allen, The British Barbarians: A Hill-Top Novel (London: John Lane, 1895), p. xviii.

${ }^{43}$ Wilde, 'The Preface' to The Picture of Dorian Gray (London: Ward Lock, 1891), p. vi.
} 
286), and he returns home to find that he has left his front door open. He has only been in the Park for a few minutes, but on his return to domesticity he finds his home subtly changed. Guildea tells Murchison that he is sure that 'somebody had got into the house in my absence' and that this person and himself 'had simultaneously formed the project of interviewing each other'(pp.287-88). If the over-worked Professor was looking for a distraction from his studies, or a conversation to break the monotony of his labour, then his behaviour is at the very least unpredictable and possibly dangerous. It would be easy for a potential burglar to enter the property he had left so invitingly open.

As Antony Clayton comments, Hyde Park was notorious throughout the nineteenth century as a site of sexual transgression: 'The naked statue of Achilles [...] was a favourite meeting place' for homosexuals, a point reinforced by Harry Cocks, who observes that the Park at night was 'the resort of rough-sleepers, criminals, civilian blackmailers and the homeless', not to mention guardsmen, who were notorious for their willingness to sell sexual favours to other men. It was, therefore, a place 'of license and danger'. ${ }^{44}$ The Uranian poet, André Raffalovich, included 'Hyde Park - November', a 'not very subtle celebration of same-sex male desire' in his The Thread and The Path (1895)..$^{45}$ On his first visit to Guildea, Murchison encounters 'soldiers, chattering women and giggling street boys in their Sunday best' loitering near Marble Arch (p. 271), details which at once give the story a little local colour and provide a glimpse of its sexual context for those able to discern their significance. Max Beerbohm had, after all, told Reggie Turner that 'Her Majesty's uniform' was 'another form of female attire' in a letter sent during the Wilde trials. ${ }^{46}$ The Park's 'cultural and physical organization informed a distinctive sexual microgeography', says Matt Houlbrook, and its criminal reputation prompted numerous complaints. ${ }^{47}$ Cocks quotes a deputation to the Home Office from the London Free Church Council, which in 1912 drew attention to the fact that indecency, sexual intercourse and sodomy are being constantly carried on in various parts of [Hyde] Park especially after dark'. ${ }^{48}$ Havelock Ellis's Sexual Inversion (1897) included discussion of Hyde Park prostitutes; Wilde's friend George Ives even argued in the press against lighting or closing London's parks at night in order to create 'spoonitoriums' allowing the same degree of sexual freedom as might be enjoyed in Berlin's Thiergarten. ${ }^{49}$ Such was the reputation of the place that 'Hyde Park Offences' became an almost proverbial term among lawyers and policemen.

By venturing there so late at night, Guildea is taking a considerable risk, the more so as the story that follows his, 'The Lady and the Beggar', has the wealthy Mrs Errington announce 'Hyde Park swarms with bad characters'. ${ }^{50}$ The narrator amplifies this assertion:

${ }^{44}$ Clayton, p. 183; H. G. Cocks, Nameless Offences: Homosexual Desire in the $19^{\text {th }}$ Century (London: I.

B. Tauris, 2003), p. 58.

${ }^{45}$ Denisoff, p. 110.

${ }^{46}$ Beerbohm to Turner, 3 May 1895, quoted in Peter Rawlings, Henry James and the Abuse of the Past (Basingstoke: Palgrave Macmillan, 2005), p. 33.

${ }^{47}$ Matt Houlbrook, Queer London: Perils and Pleasures in the Sexual Metropolis, 1918-1957 (Chicago:

University of Chicago Press, 2005), p. 54

${ }^{48}$ Cocks, p. 59.

${ }^{49}$ Matt Cook, London and the Culture of Homosexuality, 1885-1914 (Cambridge: Cambridge

University Press, 2003), pp. 89, 141.

${ }^{50}$ Hitchens, 'The Lady and the Beggar', p. 354. 
The clocks of the town had struck eleven, and most of the legitimate sweethearts who make the Park their lover's walk had gone home, leaving this realm of lawns and trees and waters to the night-birds, the pickpockets, the soldiers, and the unhealthily curious persons over whom it exercises such a continual and gloomy fascination. ${ }^{51}$

Heterosexual 'courting couples' are 'legitimate', but the bacchanalia to which the Park plays host in the hours of darkness is an altogether more transgressive rite. Guildea may be absorbed in his research, but he must surely be aware of the Park's reputation. Uncertain whether the figure he has seen on the bench is 'man, woman or child' (p. 285), the Professor is nevertheless willing to venture into the darkness to find out. This may be 'unhealthy curiosity', compassion for the homeless, or something a little more speculative, even predatory. Guildea's house may be sensually inert, but the atmosphere of Hyde Park Place seems charged with dangerous energies.

Perhaps it is these which drive away Pitting, the Professor's butler. After Guildea tells him something of what has been going on since the spirit's arrival and begs him to listen to his plight, Pitting immediately resigns. He tells his employer that he is paid to be a butler, 'not to sit up all night with people' (p. 310). Guildea wonders whether the 'machine-like' man is 'cold' or frightened (p. 311), but here we might ask again what he is frightened of. Clearly, Pitting is ill at ease with a social superior's self-revelation, but he may sense something more incriminating. He is certainly unwilling to remain under the same roof as the Professor if the Professor is embarking on clandestine nocturnal business with mysterious persons encountered in the park, though he says no more. Tellingly, Guildea's maid and cook are not asked for their comments.

At the finale of the story, when Guildea's hatred has driven the apparition outside, Father Murchison goes into the street, intrigued by 'something' on a bench that is 'huddled together very strangely' (p. 338). 'Was there really something that had indeed come to the Professor? And had it finished its work, fulfilled its desire and gone back to its former existence?', he wonders, his language suggestive of a transient, possibly even commercial sexual encounter. Murchison enters the Park in clerical dress, only to be grabbed by a policeman who 'ey[es] him suspiciously' and asks 'What are you up to?'. The worldly priest instantly realizes that, hatless (unlike the nominally respectable Guildea) and fascinated by the occupant of a nearby bench, he cuts a dubious figure. He at once 'thrust[s] some money into the constable's hand' (p. 338) and proceeds to the seat without further molestation, a matter-of-fact event that reveals much about the close relationship between sex, money, and corruption in 1890s London. In The Green Carnation, Hichens joked that a policeman was called a 'copper' 'because you can only bribe him with silver, or with gold'. ${ }^{52}$ Arrested following his involvement in a brawl between a group of female prostitutes and two policemen in Piccadilly in October 1895, the eminent evolutionist Professor Edwin Lankester found himself in court, charged with obstruction. In a spirited speech, he called for a departmental enquiry into the conduct of Metropolitan Police officers, for it was 'a matter of common report', he said, 'that they levy blackmail on the women of the street, and receive bribes from those they have arrested ${ }^{53}$ Murchison's unblushing willingness to pay off a policeman shows that he understands street life in ways that Guildea does not, and also that the police are quite willing to arrest men on suspicion. Murchison has, after all, committed no crime beyond being in a public place without acceptable headgear.

\footnotetext{
${ }^{51}$ Ibid., p. 357.

${ }^{52}$ Hichens, The Green Carnation, p. 109.

${ }^{53}$ Times, 4 October 1895, quoted in Freeman, p. 184.
} 
Hichens's story is therefore set against a background of moral anxiety concerning men and urban public spaces. Although Guildea's unwanted intimacies occur in private (or in Paris), his encounter with the spirit is in many ways akin to the furtive assignations characteristic of the sexual climate post-Labouchere. ${ }^{54}$ The scandalous Oxford student magazine, The Chameleon (1894), much discussed at Wilde's libel trial for its inclusion of his 'Phrases and Philosophies for the Use of the Young' and probably known to Hichens, was subtitled, 'A Bazaar of Dangerous and Smiling Chances', a quotation from Robert Louis Stevenson's More New Arabian Nights (1885) which, as Neil McKenna notes, suggests 'the eye contact used by men in dangerous street pick-ups ${ }^{35}$ Whether or not Guildea, or Murchison for that matter, is actually homosexual is less important than the connotations of the illicit and transgressive that surround their activities. As Eve Kosofsky Sedgwick famously argues, during the late nineteenth century it became increasingly difficult to distinguish between 'the most intimate male bonding', which was socially permitted, and 'the remarkably cognate homosexuality', which was fiercely proscribed. ${ }^{56}$ This leads to the question of whether the Professor is being punished for shutting love out of his life, or whether his fate is a consequence of the nature of that love or, at least, the societal perception of it. Anna Lea Merritt initially refused to allow reproduction of her painting Love Locked Out (1890), alarmed that viewers were interpreting it as 'a symbol of forbidden love' instead of recognizing it as an image of the impossibility of her being reunited with her dead husband. ${ }^{57} \mathrm{It}$ may be that the figure huddled on the bench is another symbol of 'forbidden love'. After all, whatever was outside Number 100 resisted precise identification or enunciation, and the spirit that haunts Guildea can only utter noises of 'amiable idiocy' rather than discernible speech. It possesses the 'voice of a love-sick idiot, sickly yet determined' (p. 315), and Murchison finds it 'cooing', 'querulous', 'full of sickly suggestion yet hard, even dangerous in its intonation' (p. 316). ' $[\mathrm{H}]$ uman' yet at the same time 'oddly sexless', the voice, as imitated by Guildea's parrot, Napoleon, combines 'sickliness' and 'strange indelicacy' with 'a die-away softness and meretricious refinement' before fading away 'in a sort of husky gasp' (p. 317). Murchison is unable to 'distinguish any words' or 'decide on the voice's age or sex' (p. 317), but the descriptions of it make it seem not unlike the 'unmanly' simpering associated with fin de siècle homosexuals such as Jack Saul, the male prostitute notorious for his involvement in the Cleveland Street Scandal of 1889, or some of the prosecution witnesses at Wilde's criminal trials. Is the ghost the departed spirit of such a character? To borrow from Bosie Douglas's most notorious poem 'Two Loves' which appeared alongside 'Phrases and Philosophies' in The Chameleon in December 1894, this is a 'love that dare not' or even cannot, 'speak its name', one which Guildea is determined to cast out and deny as incompatible with his life as a paradoxically humanitarian yet misanthropic scientist. ${ }^{58}$

\footnotetext{
${ }^{54}$ Hichens met Labouchere a number of times and pronounced him 'a very kind man, in spite of his perhaps cynical, and certainly ironical, mind'. Yesterday, p. 110.

${ }^{55}$ McKenna, p. 432.

${ }^{56}$ Eve Kosofsky Sedgwick, The Epistemology of the Closet (Oakland: University of California Press, 1990), p. 186.

${ }^{57}$ Lionel Lambourne, Victoria Painting London: Phaidon, 1999), p. 319.

${ }^{58}$ Lord Alfred Douglas, 'Two Loves' in Casper Wintermans, Alfred Douglas: A Poet's Life and His Finest Work (London: Peter Owen, 2007), pp. 210-11. The poem is dated '18 Cadogan Place,
} 
As Kerry Powell writes, when 'Two Loves' was discussed at Wilde's second criminal trial, the playwright hid behind 'a blizzard of textual citations' which refused to honestly answer the question of what 'the love' might be. ${ }^{59}$ Wilde understood his Plato well enough to know how stringently Socrates distinguished between the definition and the mere example, and his rhetorical flight concerning 'that deep spiritual affection that is as pure as it is perfect' somehow elided quotations from Dorian Gray and a set of elevated cultural allusions far removed from the realities of activities which, after all, could scarcely be admitted in a court of law. ${ }^{60}$ Wilde, cornered, was forced to misrepresent himself in the language of his prosecutors. By contrast, the spirit, though far less eloquent than the dramatist, is operating outside (and beyond) legal constraints and can therefore say what it is and wants. Unfortunately, neither Guildea nor Murchison are prepared to listen, understand, or recognize their own repressed capacity to speak its language. They perceive suggestion and implication, and recognize an importuning physical presence. By contrast, Napoleon the parrot enjoys the spirit's caresses and repeats its blandishments in ways that defy the scientist and the priest. Perhaps the implication here is less that the love offered is 'beastly' or 'lower' than that it is natural. That the spirit makes Guildea feel 'admired, loved, desired' (p. 320) is the worst aspect of the entire affair. He is no stranger to admiration on the lecture platform even if he 'does not encourage adoration' (p. 284), and Father Murchison's friendship does not seem to disconcert him, since he distinguishes between 'reasonable liking' which he approves, and 'anything more' which he finds 'irksome' (p. 278). Desire however is irrational, ungovernable, disruptive, and dangerous - this is love not as agape or caritas but as eros: '[B]ut where desire takes charge', writes Philip Larkin, 'readings will grow erratic' ${ }^{61}$ One assumes that scientific experiments, whatever Guildea's may be, will become similarly untenable in such circumstances.

What defence can be offered against an apparently irresistible force, the 'morbid' attraction or forbidden or inadmissible love that erodes body and mind alike? If Hichens was fundamentally alarmed by heterosexual intimacy, as Bleiler suggests, and yet also 'abhors any hint of homosexual love', celibacy offered a way of life that allowed him to remain well-connected (his memoirs are notably gossipy) without ever having to take the wishes of others into account. ${ }^{62}$ Celibacy may have been for him a way of negotiating with desires he could not openly acknowledge, distrusted himself for harbouring, or was fearful of admitting because of stringent legal penalties, though it might also be perceived as part of a more complex sexual economy.

\section{Living and $\mathrm{D}(\mathrm{en}) \mathrm{ying}$}

There were many reasons to pursue, willingly or unwillingly, a celibate life in the Britain of the late nineteenth and early twentieth century. The most obvious of these is what might be termed passive celibacy, or celibacy as accident of circumstance. Women outnumbered men in Britain in

September 1892', and first appeared in the solitary number of The Chameleon (December 1894), pp.26-8.

${ }^{59}$ Powell, Acting Wilde, p. 158.

${ }^{60}$ The Trials of Oscar Wilde, 1895, ed. Tim Coates (London: The Stationery Office, 2001), pp. 14849.

${ }^{61}$ Philip Larkin, 'Deceptions' (1955), in The Complete Poems, ed. by Archie Burnett (London:

Faber, 2012), p. 41.

${ }^{62}$ Clute, p. 465. 
the 1890s, a fact commemorated by Gissing's The Odd Women (1893), and many were unable to marry having failed, for one reason or another, to secure a partner when deemed most eligible. ${ }^{63}$ Men were often unable to marry through poor financial prospects, jobs which denied them a stable home (such as being in the army or navy), or because they lost out to their romantic rivals. The old, the disabled, the infirm, the congenitally ill, the person whose responsibilities to their family or their employer precluded a life beyond such commitments, all found themselves celibate; 'respectable' men did not admit to recourse with prostitutes, while men and women attracted to their own sex could struggle to find their desires reciprocated, particularly if they did not live in large towns or cities. Against this however should be set active or elective celibacy, whereby a sexless life was a deliberate choice and commitment. The Roman Catholic clergy represented the most familiar version of this decision, but during the 1890s there was growing agitation amongst feminists and other political radicals that the sexual double standard be addressed, with the notion that 'lack of chastity was understandable and excusable in men, but unforgivable in a woman' a particularly contentious shibboleth. ${ }^{64}$ Oaths of pre-marital chastity, which would, reformers hoped, allow men and women to socialize and work together on an equal footing, were much discussed in 'advanced' circles. To be chaste was, to borrow from Lucy Bland, to 'banish the beast' of 'selfish, egotistic, sexual lustfulness' which 'supposedly lay within us all' but was usually deemed 'closer to the surface in men'. ${ }^{65}$ Clearly celibacy prompted by the concerns of gender politics is quite different from celibacy that arises from lack of sexual opportunity (or will), but neither of these models quite fits with the concerns of Hichens's story.

'How Love Came to Professor Guildea' foregrounds celibacy from its opening page. Both Guildea and Murchison are celibate, the priest because he belongs to 'an Anglican order which forbade him to marry', the scientist because 'he had a poor opinion of most things but especially of women' (p. 270). Murchison's celibacy is endorsed throughout the story - it is divinely sanctioned and, since no man can serve two masters, allows him to concentrate his affection on his flock. Whether this means that Murchison has found a culturally-approved means of sublimating his desires, or whether he is naturally saintly is unclear, though the fact that he has 'an East End lad' to run his errands who 'would do more for me than put coals on my fire' (p. 278) acquires a new significance when the priest reveals his horror at the infatuation of 'a terrible, pale woman who for a time haunted all the churches in which he ministered' (p. 316). ${ }^{66}$ Murchison's higher calling means that celibacy is an exalted condition: that he remains Anglican suggests both Hichens's sympathy with High Church practices and his artful recognition that a largely Protestant readership would be more likely to endorse Murchison's views as an Anglican than they would if he had crossed over to Rome, especially at a time when Catholicism carried with it decadent associations. At the same time, the more knowing of Hichens's readers may

${ }^{63}$ 'While some women consciously opted for spinsterhood, for the majority of women it was not a choice,' writes Lucy Bland, pointing out that in 1885, there were 1055 to every 1000 men, a 'demographic imbalance' largely explained by 'the higher death rate of males, and the higher rate of male emigration, three males emigrating for every one female'. Lucy Bland, Banishing the Beast: English Feminism and Sexual Morality, 1885-1914 (London: Penguin, 1995), p. 162.

${ }^{64}$ Ibid., p. xiii.

${ }^{65}$ Ibid.

${ }^{66}$ In 'Sea Change', the unmarried Hamilton's search for his ideal model leads him to seek out boot-blacks, newspaper sellers, and children playing in Trafalgar Square. 
have acknowledged Anglo and Roman Catholicism's appeal to men whose 'buried lives', as Matthew Arnold might have put it, 'forced them into modes that required metaphorical expression of homoeroticism?. ${ }^{67}$

Murchison's celibacy is thus culturally endorsed in two respects. For the majority of Hichens's readers, he is fulfilling a high-minded priestly vocation, while for those who relished the in-jokes of The Green Carnation, he may well be a man with a secret, perhaps one of those priests who practiced 'the eroticization of slum boys - elevated to celestial beauty by their role in the mass' - when ministering to 'impoverished parts of the city' and who consequently cross the boundary between caritas and concupiscence. ${ }^{68}$ The priest carries out his mission without earthly ties, ministering to the East End poor and the stricken Guildea with equal energy, even if he seems to have withheld his benediction and his pity from the 'terrible, pale woman' who follows him on his rounds.

Guildea's celibacy, by contrast, receives no such indulgence or approval. The Professor's 'habitual manner' is 'one of distrust and interrogation' (p. 269) - he lacks Murchison's capacity for faith - and it is 'impossible to suppose that, in his busy life, he found any time for love, either of humanity in general or of an individual' (p. 270). That his unspecified scientific investigations confer 'immense benefits upon the world' (p. 270) is an incidental bonus, since Guildea maintains his work is 'undertaken merely for its own sake' (p. 275), rather than to fulfil humanitarian objectives. When Murchison notes the 'serious' omission of 'any desire for close human sympathy' in his life (p. 274), the Professor refers, haltingly, to 'my present condition of-my present non-affectional condition' (p. 275), seeming to hint through his quasi-scientific terminology at the potential for change. This is made more apparent later in the story, when he suddenly asks Murchison, 'D'you think I'm an attractive man?', a question which receives the answer, 'Do you mean attractive to the opposite sex?' (p. 282). Guildea's question nominally concerns the likelihood of him inspiring 'irresistible' attraction in others (p. 282), but when Murchison reacts with such surprise - 'Father Murchison jumped [...] 'Bless me!" he ejaculated' (p. 282) - there is a clear hint that he has perhaps recognized an aspect of Guildea's sexuality that the Professor himself is inclined to evade.

As Bleiler shows, denial usually triumphs over desire in Hichens's work and 'those who disagree with the properly behaving representatives of established religion are invariably humbled'. ${ }^{69}$ Such are the story's submerged sexual suggestions that it could be imagined that for some years before the story begins, Guildea succeeded in 'banishing the beast' and living a life of scientific industry. Unfortunately, once he moved from Birmingham to London, he found the 'morbid pleasures' of the metropolis began to act upon him to deleterious effect. Working, like those other professors who stalk fin de siècle London in the fiction of Conan Doyle and Conrad, outside of institutional obligation, Guildea is answerable to no one, secure in the house that doubles as his laboratory and able to keep his secrets locked away even from himself, a Doctor Jekyll who never quite transforms into Mr Hyde. Yet, if he has managed to sublimate his desires into a life of sober research, it was unwise of him to move to Hyde Park Terrace, or, for that matter, to strike up a relationship with Murchison. By dropping his guard even slightly with the

\footnotetext{
${ }^{67}$ Frederick S. Roden, Same-Sex Desire in Victorian Religious Culture (Basingstoke: Palgrave Macmillan, 2002), p. 227.

${ }^{68}$ Roden, pp. 238, 4.

${ }^{69}$ Bleiler, p. 110.
} 
priest, or indeed with Pitting, Guildea renders himself vulnerable to the entry of the mysterious spirit, a visitor who seeks to merge with the flesh in ways that Guildea cannot countenance.

Perhaps however, Guildea's real offence is not to cut himself off from affection but to channel his repressed energies into the wrong field. Had he shared Murchison's vocation, he could at once have been celibate and loving, gratifying his own desires (up to a point) while fulfilling the highest human aim of serving God: his name, after all, does mean 'blessed'. As it is, however, his investment in science, coupled with the vanity that his fame wins him, means that he falls foul of Hichens's punitive code. Guildea should certainly have 'lived differently', but the story's final lines should not be read merely as an ironic ambiguity or an excuse for Christian homilies. Instead, the tale shows how Hichens was able to exploit the increasing tendency of the ghost story to dramatize the experience of being haunted rather than the chilling appearances of the apparition, creating in the process a memorable supernatural fiction alongside a more veiled account of sexual secrecy and its consequences. It is thus more than a little ironic that the Speaker's reviewer felt that Tongues of Conscience 'suffer[ed], like most of his work, from a lack of repression'. ${ }^{70}$

Dr Nick Freeman, Loughborough University

N.Freeman@lboro.ac.uk

School of the Arts, English and Drama

Loughborough University

Loughborough

Leicestershire

LE11 3TU

${ }^{70}$ Speaker, 27 October 1900, p. 104. 